\title{
EFFECTS OF LARGE DOSES OF ANABOLIC STEROIDS
}

\author{
R. A. HARKNESS, ${ }^{*}$ Ph.D., F.R.C.P.E., \\ B. H. KILSHAW, ${ }^{*}$ B.Sc. and B. M. HOBSON, † Ph.D. \\ Departments of Paediatric Biochemistry, (R.H.S.C.E.) ${ }^{*}$ and Obstetrics and Gynaecology, (S.M.M.P.)t, \\ University of Edinburgh, EH9 1 LJ, U.K.
}

The effects of large doses of anabolic steroids have been difficult to study as these have generally been used therapeutically in doses which are less than those needed for replacement of physiological androgen production. About $15 \mathrm{mg}$ of methandrostenolone a day is required for androgen substitution (Liddle \& Burke, 1960) whereas the therapeutic dose is generally $5 \mathbf{m g}$ a day and does not have large observable effects, especially on the selfregulating system of androgen production itself. Although it has been alleged that some athletes take large amounts of anabolic steroids, this has been understandably difficult to study, (Wade, 1973). Large doses of oxymetholone have been used in aplastic anaemia; however, this occurs mainly in childhood, therefore effects on the reproductive system are not detectable (Allen et al., 1968).

Marked effects on the testes and accessory sex organs are to be expected in man because anabolic steroids were developed from their preferential effects on the rat 'levator ani' muscle which is part of the male reproductive system in that animal (Hayes, 1965). In the rat, anabolic steroids have marked effects on the testes and accessory sex organs as well as causing arrest of spermatogenesis (Kincl et al., 1965). The most sensitive system is probably hypothalamus - anterior pituitary - testes, as shown by the reduction in gonadotrophin output by one of our patients receiving large doses of oxymetholone. Direct effects of oxymetholone, and possibly other steroids, on the gonads also seem probable as large doses of oxymetholone significantly shorten the life of the corpus luteum in women (Klaiber et al., 1973). This effect is believed to be mainly due to a direct action on steroidogenesis since oxymetholone is a potent inhibitor of some biosynthetic enzymes (Ferrari \& Arnold, 1963 a $\&$ b). Our studies of an athlete taking large doses of methandrostenolone, showed a greater effect on testosterone output than on gonadotrophin excretion; this may be consistent with some direct effects on the gonads.

Anabolic steroids appear to be weak or low dosage androgens which act over longer periods of time than compounds which are strongly androgenic. Such prolonged action can be produced by metabolism to a biologically active compound in contrast to the usual inactivation. This may be the mechanism for oxymetholone (MacDonald et al., 1973; Kincl et al., 1965). Pro- longed action also occurs when the active compound is longed action also occurs when the active compound is $\vec{O}$ more slowly metabolised by the usual systems for steroid inactivation; methandrostenolone is scarcely $\vec{\omega}$ metabolised by the systems for steroid reduction and $\vec{D}$. conjugation (Adhikary \& Harkness, 1971). Such metabolism occurs largely in the liver and effects on hepatic ${ }_{0}$ function have often been noted, especially for 17-alky- iv lated steroids, and appear to be dose related (Liddle \& Burke, 1960; Lennon, 1966).

\section{Effects on the Male Reproductive System}

Studies on two patients taking large doses of anabolic $\overrightarrow{\overrightarrow{0}}$ steroids have been performed using the methods defined by Kilshaw and his colleagues (1975). The first man had been treated elsewhere for severe osteoporosis with doses of oxymetholone of $250 \mathrm{mg}$ a day. The endocrine studies in Table I show a reduction in the output of the gonadotrophin, ICSH (Interstitial cell stimulating hormone) or LH, (Luteinising hormone) and testosterone. $\mathbb{Q}$ When treatment was stopped his gonadotrophin output $\overrightarrow{\vec{a}}$ increased for about 6 weeks to return to a high level. This high level is probably a consequence of testicular changes from his previous bilateral cryptorchidism corrected at the age of 11 years. At these levels of ICSH his testosterone output is in the lower half of the normal range when on 'physiological replacement' treatment with methenolone oenanthate. FSH (follicle stimulating hormone) output is not raised despite a low sperm count 8 which biopsy showed to be associated with some arrest of spermatogenesis at the spermatid level. Serial liver 0 function tests when on treatment with the very large doses of oxymetholone, were normal - Bilirubin about $\frac{7}{0}$ $0.6 \mathrm{mg} / 100 \mathrm{ml}$ and alkaline phosphatase $70-80 \mathrm{IU} / 1$. were at about the upper limit of the normal range.

The second man, aged 26 , was an athlete who was $N$ treating himself with large doses of up to $100 \mathrm{mg}$ a day of methandrostenolone. This, combined with physical $\omega$ training, had produced a weight increase of $12.7 \mathrm{Kg}$ to reach $95 \mathrm{Kg}$ over 2 years. However, about 2 years after $\stackrel{0}{\mathrm{C}}$ starting self-medication, he consulted his doctor about $\stackrel{\Phi}{\Phi}$ some difficulties in his previously normal married life.

The findings in this patient have been described in $\frac{0}{\mathbb{D}}$ some detail by Kilshaw and his colleagues (1975). His $\stackrel{\stackrel{\rho}{\mathbb{D}}}{\circ}$ testosterone production was markedly reduced with a $\cong$ low FSH and normal ICSH output (Table II). The ICSH? excretion had risen markedly with decreasing dosage. 
TABLE I

\section{Effects of Anabolic Steroids on Anterior Pituitary and Testicular Function}

Male, 26 years old

Severe, generalised osteoporosis

Bilateral orchidopexy at 11 years of age

\begin{tabular}{|c|c|c|c|c|}
\hline \multirow{2}{*}{$\begin{array}{l}\text { Weok of } \\
\text { Study }\end{array}$} & \multirow{2}{*}{ Treatment } & \multicolumn{3}{|c|}{ GONADOTROPHINS } \\
\hline & & $\begin{array}{l}\text { ICSH } \\
\text { (IU/24h) }\end{array}$ & $\begin{array}{l}\text { FSH } \\
(1 U / 24 h)\end{array}$ & $\begin{array}{l}\text { Testoste- } \\
\text { rone } \\
(\mu g / 24 h)\end{array}$ \\
\hline \multirow[t]{5}{*}{1} & Oxymetholone, & 17.3 & - & \\
\hline & $250 \mathrm{mg} /$ day & 27.2 & - & 10.4 \\
\hline & & 42.7 & - & \\
\hline & & 23.7 & - & \\
\hline & & 17.3 & - & \\
\hline \multirow[t]{2}{*}{4} & & 49.3 & & \\
\hline & & 71.3 & & \\
\hline 6 & 226.7 & & & \\
\hline \multirow[t]{3}{*}{39} & Methenolone & & & \\
\hline & oenanthate & 221.3 & 1.6 & 38.8 \\
\hline & $100 \mathrm{mg} \mathrm{im} / 4 \mathrm{v}$ & & & \\
\hline
\end{tabular}

TABLE II

Effect of Methandrostenolone, about $60 \mathrm{mg} / \mathrm{day}$, on

Testicular Endocrine Activity

Week 28 Approx. Normal Range

$\begin{array}{llrl}\text { Plasma } & \text { testosterone } & 67.8(5) * & (400-1220) \mathrm{ng} / 100 \mathrm{ml} \\ \text { Urine } & \text { testosterone } & 4.6(2) & (30-80) \mu \mathrm{g} / 24 \mathrm{~h} \\ & \text { pregnanetriol } & 0.13(2) & (0.4-1.0) \mathrm{mg} / 24 \mathrm{~h} \\ & \text { LH or ICSH } & 43.6(2) & (18-54) \mathrm{IU} / 24 \mathrm{~h} \\ & \text { FSH } & 1.3(2) & (2.3-7.1) \mathrm{IU} / 24 \mathrm{~h} \\ & & & \end{array}$

* number of estimations

However, one week after stopping self-medication, his testosterone output was still subnormal at $21 \mu \mathrm{g} / 24 \mathrm{~h}$. Withdrawal effects are therefore to be expected even when dosage is gradually reduced to about $25 \mathrm{mg}$ a day, as in this case.

The effect of methandrostenolone on muscle was monitored by creatinine output which was raised at about $3 \mathrm{~g} / 24 \mathrm{~h}$ and did not correlate with dosage which varied from $100-25 \mathrm{mg}$ of methandrostenolone a day. One week after stopping a dose of $25 \mathrm{mg} /$ day his creati- nine output was still raised at $3.75 \mathrm{~g} / 24 \mathrm{~h}$ suggesting that there is a considerable lag in effects on muscle.

The relative constancy of creatinine output suggests that there is little additional benefit from large doses of anabolic steroids. Liddle \& Burke (1960) showed that no further weight increase was produced by doses over 2.5 $\mathrm{mg} /$ day. Nitrogen retention in healthy men also showed little increase despite increasing dosage (Kruskemper, 1968). In contrast, earlier work on rats had shown a proportionate weight increase (Desaulles et al., 1959). The available evidence suggests that the response of androgen sensitive end organs in man, appears to be nearly maximal at adult androgen levels. However, it must be admitted that any effects under about $5-10 \%$ would probably not be detectable in many measurements of end organ responses.

In both patients, large doses of anabolic steroids have reduced the output of testosterone and gonadotrophins; similar effects have been noticed in rats (Boris et al., 1969). Some reversal of these effects has been seen in both patients on stopping treatment.

A low sperm count at the time of the studies in Table II suggested that methandrostenolone may be reducing spermatogenesis. The total sperm count, volume and motility was reduced with some increase in abnormal forms as compared to the normal mean (McLeod, 1951). It may also be relevant that this man and his wife were using the unreliable 'safe' period for contraception without mishap for $2-3$ years.

Marked effects on spermatogenesis are reversible in rats (Kincl et al., 1965). However, spermatogenesis is clinically disturbed in man more often than testicular endocrine function. In addition, treatment of male infertility is often unsatisfactory. Although the effects of treatment with the oestrogenic and progestational steroids in women have been readily reversible, these have been used at the recommended dosage. Despite much care in the use of these drugs, some increased disease incidence has been found in large surveys. The concealment of prolonged self-medication with large doses of anabolic steroids renders such surveys difficult but the above evidence suggests that more data is needed.

The duration and extent of self-medication by the athlete was determined by estimating the urinary metabolites, 6\%-hydroxy methandrostenolone and the 17-epimer using carbon skeleton chromatography (Adhikary \& Harkness, 1969 a \& b). The 'total' recoveries of the stated dose were generally similar to those obtained from normal therapeutic doses (Harkness et al., 1974), but the excretion of the 17-epimer was increased relative to the $6 \beta$-hydroxy compound, suggesting some alteration of drug metabolism with in- 
creasing dosage. There may be some limitation of hydroxylation which is an inactivation process for many drugs and hormones. The administration of other drugs simultaneously with anabolic steroids might cause either increased or decreased effects, depending on the nature of the other drug. For example after methandrostenolone administration, cortisol metabolism (James et al., 1962) and phenylbutazone metabolism (Hvidberg et al., 1968), are slowed as shown by increased plasma half lives.

Our second patient, the athlete, said he had also taken thyroxine. The results in table III suggest that thyroxine will diminish the effects of any simultaneous administration of methandrostenolone by increasing its metabolism and excretion.

In conclusion, large doses of anabolic steroids, 10-25 times the therapeutic dose, have definitely reduced testosterone and gonadotrophin output. The limited evi-
TABLE III

Effect of Hypo- and Hyperthyroidism on the Metabolism of Oral Methandrostenolone

\begin{tabular}{|c|c|c|c|}
\hline \multirow[b]{2}{*}{ Clinical condition } & \multirow[b]{2}{*}{ Patients } & \multicolumn{2}{|c|}{$\begin{array}{l}\text { Mean Percentage of } 5 \mathrm{mg} \text { dose } \\
\text { recovered from urine as }\end{array}$} \\
\hline & & 17-epimer of $M$ & $6 \beta$-hydroxy $M$ \\
\hline Hypothyroidism & 3 & 1.5 & 1.3 \\
\hline Hyperthyroidism & 2 & 4.3 & 4.0 \\
\hline
\end{tabular}

dence available suggests some reduction in spermatogenesis. There were also subtle alterations in hepatic 8 function. At present there would not appear to be ade- iv quate evidence for estimating the real, but possibly $\partial$ slight, risk of such changes becoming irreversible or 0 progressive.

\section{REFERENCES}

Adhikary, P. M., and Harkness, R. A. (1969a). Determination of the carbon skeletons of microgram amounts of steroids and sterols by gas chromatography after their high temperature catalytic reduction. Anal.Chem., 41, 470.

Adhikary, P. M., and Harkness, R. A. (1969b). Production of the parent hydrocarbons from steroid drugs and their separation by gas chromatography. J.Chromatog., 42, 29.

Adhikary, P. M., and Harkness, R. A. (1971). The use of carbon skeleton chromatography for the detection of steroid drug metabolites; the metabolism of anabolic steroids in man. Acta endocr.(Kbh.), 67, 721.

Allen, D. M., Fine, M. H., Necheles, T. F., and Damashek, W. (1968). Oxymetholone therapy in aplastic anaemia. Blood, 32, 83.

Boris, A., Stevenson, R. H., and Trmal, T. (1969). Comparative androgenic, myotrophic and antigonadotrophic properties of some anabolic steroids.Steroids, 15,61 .

Desaulles, P. A., Krakenbuhl, Ch., Schuler, W., and Bein, H. J. (1959). Experimental study on Dianabol, a new anabolic agent. Schweiz.Medizin.Wochenschr., 89, 1313.

Ferrari, R. A., and Arnold, A. (1963a). Inhibition of $\beta$-hydroxysteroid dehydrogenase 1. Structural characteristics of $\frac{D}{2}$ some steroidal inhibitors. Biochim. Biophys.Acta, 77, 349.

Ferrari, R. A., and Arnold, A. (1963b). Inhibition of $\beta$-hydroxysteroid dehydrogenase II. Kinetics and pH effect. Biochim.Biophys.Acta, 77, 357.

Harkness, R. A., Scott, R. D. M., and Strong, J. A. (1974). Physiological and pharmacological factors affecting the 63-hydroxylation and 17-epimerization of methandrostenolone. Biochem.Soc. Trans., 2, 119.

Hayes, K. J. (1965). The so called 'levator ani' of the rat. Acta endocr. (Kbh.), 48, 337.

Hvidberg, E. F., Dayton, P. G., Read, J. M., and Wilson, C. H. (1968). Studies of the interaction of phenylbutazone, oxyphenbutazone and methandrostenolone in man. Proc.Soc.exp.Biol.Med., 129, 438.

James, V. H. T., Landon, J., and Wynn, V. (1962). Effect of an anabolic steroid (methandienone) on the metabolism of cortisol in the human. J.Endocr., 25, 211. 
Kilshaw, B. H., Harkness, R. A., Hobson, B. M., and Smith, A. W. M. (1975). The effects of large doses of the anabolic steroid, methandrostenolone, on an athlete. Clin. Endocr. 4, - in press.

Kincl, F. A., Macqueo, M., and Dorfman, R. I. (1965). Influence of various steroids on testes and accessory sex organs in the rat. Acta endocr. (Kbh.), 49, 145.

Klaiber, E. L., Henzl, M. R., Lloyd, C. W., and Segre, E. J. (1973). Corpus luteum inhibiting action of oxymetholone. J.clin.Endocr., 36, 142.

Kruskemper, H. L. Anabolic Steroids. Academic Press, New York (1968).

Lennon, H. D. (1966). Relative effects of $17 \alpha$-alkylated anabolic steroids on sulfobromophthalein (BSP) retention in rabbits. J.Pharmocol.exp. Therap., 151, 143.

Liddle, G. W., and Burke, H. A. (1960). Anabolic steroids in clinical medicine. Helv.Med.Acta, 27, 504.

MacDonald, B. S., Sykes, P. J., Kilshaw, B. H., and Harkness, R. A. (1973). Metabolism of the hydroxymethylene group in the anabolic steroid, oxymetholone: isolation and identification of two major metabolites. J.Endocr., 59, xviii.

McLeod, J. (1951). Semen quality in one thousand men of known fertility and in eight hundred cases of infertile marriages. Fertil.\& Steril., 2, 115.

Wade, N. (1972). Anabolic steroids: doctors denounce them, but athletes aren't listening. Science, 176, 1399. 